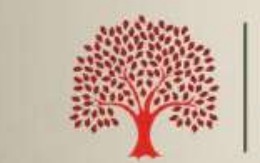

\title{
IRDCP
}

Souvenir

International Conference on

\section{Covid-19 Pandemics} Impact on

Society,

Industry

and Education

(CPISIE-2020)

December 13-14, 2020

International Research and Development Center for Publication (IRDCP) www.irdcp.org 


\section{International Conference}

\section{on}

Covid-19 Pandemics Impact on Society, Industry and Education (CPISIE-2020)

Dec 13-14, 2020

Copyright (C) 2020 International Research and Development Center for Publication

DOI: $10.22161 /$ conf.cpisie.dec.2020

\section{Publisher}

\section{IRDCP}

Email: irdcp.publication@gmail.com |conference.irdcp@gmail.com

Web: https://irdcp.org/ 


\section{$\underline{\text { About IRDCP }}$}

International Research and Development Center for Publication (IRDCP) is a nonprofit organization for promoting research and development around the world. IRDCP is the bridge between the quality publisher and researchers. It provides the platform to researchers and academicians for publication in the Scopus Indexed Journals, SCI Journals, Web of Science Journals, UGC Approved Journals, NAAS Rated Journals, Google Scholar Indexed Journals and other good quality DOI journals.

IRDCP is also a partner organization for publication in conference proceedings. We organize the International conferences for publication in SCOPUS indexed and other refereed journals as per the requirement of the authors of the manuscripts. The manuscripts submitted to IRDCP should be plagiarism free and well coherent in all sense.

The scope of publication with the IRDCP covers all type of review and research manuscripts including the Exploratory \& Explanatory Research, Descriptive \& Theoretical Research, Applied Research \& Action Research, Cross-Sectional Research, Quantitative \& Qualitative Research in the field of engineering \& technology, agriculture \& environmental, Social science \& Humanities, Literature \& Education development, Medical \& Health Science.

\section{The vision of IRDCP :}

IRDCP endeavors to promote global excellence in the field of research \& development through diligent applications of advanced technology for the holistic development of society. Also, IRDCP is committed to motivate and persuade the researchers to take up the projects for the continuous development of human society and make this world a better place to live in. The IRDCP has a steadfast commitment be the fulcrum of the ocean of knowledge around which efforts of researchers move about. 


\section{$\underline{\text { About Conference }}$}

\section{International Conference on Covid-19 Pandemics Impact on Society, Industry and Education (CPISIE-2020)}

During the worldwide lockdown due to COVID 19 pandemic, a lot of important activities have come to a halt. However, when we look at the brighter side, all of us have more time for adding to our knowledge and insights.

With this aim, to keep contributing to learning and motivation International research and development Center for publication is going to organize a two-day International Conference with the title "International Conference on Covid-19 Pandemics Impact on Society, Industry and Education (CPISIE-2020)" on Dec 13-14, 2020 through online mode.

We hope, this online mode of the conference in COVID-19 pandemic will be an appreciable step in promoting the research activities and new information between researchers, developers, students, academicians and practitioners working in and around the world by keeping the social distance in view to stop the spread of COVID-19 disease. This conference aims is to present the current researches being carried out in the field of social science and education development around the globe.

Prospective authors from academia as well as industry are invited to submit their abstracts that illustrate original/unpublished works and industrial applications describing advances and significant innovations in the field. 


\section{International Advisory Committee}

- Prof. Dr. Flávio de São Pedro Filho, Coordinator of the GEITEC / UNIR / CNPq, Brazil; Federal University of Rondônia, Brazil

- Kofand Anwar, American Stratford University, Virginia

- Dr. Raghvendra Singh, Pranveer Singh Institute of Technology, India

- Dr. Mohammed Y. Suliman, Northern Technical University, Iraq

- José G. Vargas-Hernández, Núcleo Universitario Los Belenes CUCEA, Zapopan, Jalisco C.P. 45100; México

- Dr. Payal Chadha, University of Maryland University College Europe, Kuwait

- Dr. K. Srujan Raju, CMR Technical Campus (CMRG), CSI State Student Coordinator, Telangana State, India

- Prof. Dr. Eng. Ahmed Kadhim Hussein, College of Engineering, Department of Mechanical Engineering, Babylon University, Babylon City, HIILA , IRAQ

- Dr. M. Kannan, SCSVMV, Kanchipuram, India

- Mr. Sagar Jamle, Oriental University Indore, India

- Monica Aparecida da Rocha Silva, Universidade de São Paulo, Brazil

- Mohammed Y. Suliman, Northern Technical University, Iraq

- Mohd Muntjir, College of Computers and Information Technology, Taif University, Kingdom of Saudi Arabia 


\section{Message}

I am extremely pleased to share that International Research and Development Center for Publication (IRDCP) is organizing a two days International Conference on Covid-19 Pandemics Impact on Society, Industry and Education (CPISIE-2020) on Dec 13-14, 2020.

I am sure the state of art lectures from the invited experts and the research findings of researchers, academicians, utility engineers will enrich the knowledge of all the participants. It will provide an excellent opportunity for students to learn new ideas.

I offer my best wishes to the whole team of the organizing committee, the participants, and volunteers for the grand success of the conference.

Dr. Kiran

Convenor CPISIE-2020 


\section{Message}

I am happy to know that International Research and Development Center for Publication (IRDCP) is organizing a two days International Conference on Covid-19 Pandemics Impact on Society, Industry and Education (CPISIE2020) on Dec 13-14, 2020. I am sure that, this conference would provide an ideal platform for the academicians, scholars and experts to present and exchange their research findings and Ideas.

I wish the conference a great success.

Prof. (Dr.) Hamid Saremi President (Chancellor) Assrar Higher Institute of Eduction (Deemed to be University ) Mashad - Iran (Ex- Vice- Chancellor Islamic Azad University, Quchan Branch - Iran ) 
Online education among the students of library and information science in Croatia

Darko Lacović

Stigmatization processes in SARS-CoV-2 infected patients

Carlos Miguel Ferreira ${ }^{1}$, Sandro Serpa ${ }^{2}$

Activating E-learning in Jazan University during the Pandemic

Dr Abdulbagi babiker Ali Abulhassan, ${ }^{1}$ Dr Fatima Ibrahim Eltayeb Hamid 

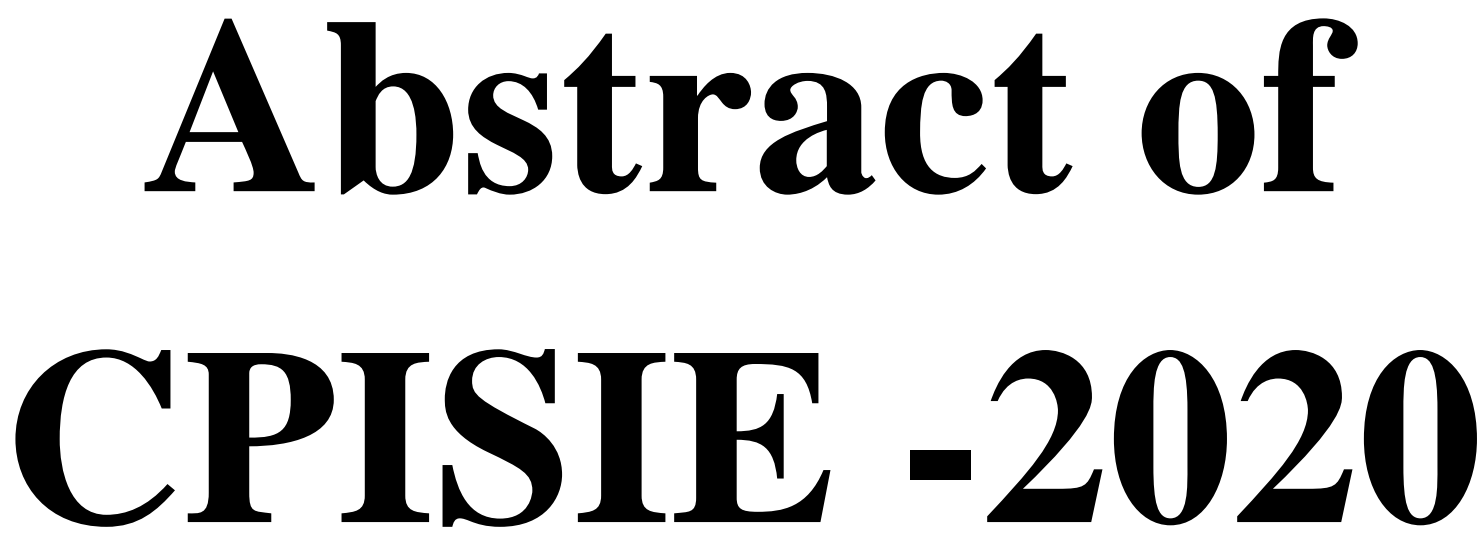


\title{
Online education among the students of library and information science in Croatia
}

\author{
Darko Lacović
}

\author{
Faculty of Humanities and Social Sciences,University of Osijek,Croatia \\ dlacovic@ffos.hr,dlacovic@gmail.com
}

\begin{abstract}
Covid-19 pandemic has affected the way in which people work. In many professions employees have to conduct their obligations from home. University teachers also had to change their working style and to perform some or most of their educational activities in an online environment. This presentation will shortly describe some findings from the most recent research that are dealing with online learning in higher education during COVID-19 pandemic. Several available studies show that authors have mainly explored the attitudes of teachers and students towards new forms of virtual education, their satisfaction with the digital technology that is used for online teaching and learning, and the difficulties which they encountered in the process of distance education. From a position of Assistant Professor I will talk abouta personal experience of online education in which participate students of library and information science at the Faculty of Humanities and Social Sciences from the University of Osijek (Croatia). Mostly I will present information and communication technology whichI use for online teaching (a platform for e-learning Moodle and virtual classrooms), explain their possibilities, and refer to some of my teaching methods, tasks and assignments for students in order to achieve learning outcomes of myonline courses. Moreover, I will describe some advantages and challenges related to interaction with the students during virtual classes, their motivation for distance learning etc.The purpose of this report is to offer some practical information to university teachers from similar scientific fields and to give them potential ideas in organization of their teaching sessions. In other words this presentation will offer some examples of distance learning practice which can be useful for university teachers who apply online education in the circumstances of the current pandemic.
\end{abstract}

Keywords - Faculty of Humanities and Social Sciences in Osijek(Croatia), library and information science, online education, students, teaching

\section{References:}

[1] Adnan, M., \&Anwar, K. (2020). Online learning amid the COVID-19 pandemic: Students' perspectives. Journal of Pedagogical Sociology and Psychology, 2(1), 45-51. https://doi.org/10.33902/JPSP. 2020261309

[2] Faculty of Humanities and Social Sciences. University J. J. Strossmayer in Osijek (n.d.).Moodle. Retrieved November 10, 2020, from https://moodle.ffos.hr/ 
[3] Kaur, G. (2020). Digital Life: Boon or bane in teaching sector on COVID-19. CLIO an Annual Interdisciplinary Journal of History, 6(6), 416-427.

[4] Lederman, D. (2020, March 18). Will shift to remote teaching be boon or bane for inline learning? Inside Higher Ed. https://www.insidehighered.com/digitallearning/article/2020/03/18/most-teaching-going-remote-will-help-or-hurt-online-learning

[5] Mishra, L., Gupta T., \&Shree, A. (2020). Online teaching-learning in higher education during lockdown period of COVID-19 pandemic. International Journal of Educational Research Open. https://doi.org/10.1016/j.ijedro.2020.100012

[6] Moodle. (n.d.). The impact of COVID-19 on online learning. Retrieved November 10, 2020, from https://moodle.com/covid19/

[7] Shahzad, A., Hassan, R., Aremu, A. Y., Hussain, A., \&Lodhi, R. N.(2020). Effects of COVID-19 in E-learning on higher educationinstitution students: the group comparison between maleand female. Quality \& Quantity. https://doi.org/10.1007/s11135-020-01028$\underline{\mathrm{Z}}$

[8] University J. J. Strossmayer in Osijek. Faculty of Humanities and Social Sciences. (n.d.).Virtualneučionice(Virtual classrooms). Retrieved November 10, 2020, from https://online.ffos.hr/ 


\title{
Stigmatization processes in SARS-CoV-2 infected patients
}

\author{
Carlos Miguel Ferreira ${ }^{1}$, Sandro Serpa ${ }^{2}$
}

\author{
${ }^{1}$ Interdisciplinary Centre of Social Sciences-CICS.NOVA, Portugal; \\ Estoril Higher Institute for Tourism and Hotel Studies, 1069-061 Lisbon, Portugal; \\ ${ }^{2}$ Faculty of Social and Human Sciences, Department of Sociology, University of the Azores; \\ Interdisciplinary Centre of Social Sciences - CICS.UAc/CICS.NOVA.UAc; \\ Interdisciplinary Centre for ChildhoodandAdolescence - NICA - UAc, theAzores, Portugal \\ Email Id: sandro.nf.serpa@uac.pt
}

\begin{abstract}
The COVID-19 pandemic has worsened social, economic and political inequalities. This communication focuses special attention on the microsocial level and the stigmatization that can potentially arise in cases of SARS-CoV-2 (infection at the origin of COVID-19 disease). Mobilizing Goffman's classic concept: stigmatization while the situation of individuals who are disabled for full social acceptance according to the regular social expectations, we analyze the socially unequal form as infected with the SARS-CoV-2 coronavirus live this situation in different ways (for example, by their social, economic, cultural) being that the most negative representations associated with discredit and are socially associated, on a regular basis, to individuals with scarce resources.
\end{abstract}

Keywords - COVID-19, SARS-CoV-2 coronavirus, stigmatisation, discredit, social inequalities

\section{References:}

[1] Ferreira, C.M., Sá, M.J., Martins, J.G., \& Serpa, S. (2020). The COVID-19 ContagionPandemic Dyad: A View from Social Sciences. Societies, 10(4), 77, 1-19. https://doi.org/10.3390/soc10040077

[2] Ferreira, C. M., \& Serpa, S. (2020). Contagions: Domains, Challenges and Health Devices. Academic Journal of Interdisciplinary Studies, 9(4), 1-14. https://doi.org/10.36941/ajis-2020-0056

[3] Goffman, E. (1988). Estigma. Notas sobre a Manipulação da Identidade Deteriorada. Rio de Janeiro: Editora Guanabara. (1 ${ }^{\mathrm{a}}$ edição de 1963)

[4] Sá, M. J., \& Serpa, S. (2020). The Global Crisis Brought about by SARS-CoV-2 and Its Impacts on Education: An Overview of the Portuguese Panorama. Science Insights Education Frontiers, 5(2), 525-530. doi:10.15354/sief.20.ar039 
[5] Sá, M. J., \& Serpa, S. (2020). The COVID-19 Pandemic as an Opportunity to Foster the Sustainable Development of Teaching in Higher Education. Sustainability, 12(20): 8525, 1-16. https://doi.org/10.3390/su12208525

[6] Sá, M. J., \&Serpa, S. (2020). COVID-19 and the Promotion of Digital Competences in Education. Universal Journal of Educational Research, 8(10), 4520-4528. doi:10.13189/ujer.2020.081020

[7] Serpa, S., \& Ferreira, C. M. (2018). Goffman's Backstage Revisited: Conceptual Relevance in Contemporary Social Interactions. International Journal of Social Science Studies, 6(10), 74-80. https://doi:10.11114/ijsss.v6i10.3659

[8] Serpa, S., \& Ferreira, C. M. (2020). Mobilization of the Classics in Sociology. Journal of Educational and Social Research, 10(3), 35-40. https://doi.org/10.36941/jesr-2020-0043. 


\title{
Activating E-learning in Jazan University during the Pandemic
}

\author{
${ }^{1}$ Jazan University,Addair,K.S.A \\ ${ }^{1}$ Jazan University, Addair, K.S.A \\ Email Id: magaddam@yahoo.com
}

Dr Abdulbagi babiker Ali Abulhassan, ${ }^{1}$ Dr Fatima Ibrahim Eltayeb Hamid

\begin{abstract}
During the lockdown period due to COVID 19 pandemic, many activities were badly affected. Educational sector was not an exception. As it is necessary to keep continuity of learning process, educational instiutions decided to lead the challenge. Then a great need for discussions and research on the issue arose.The current paper aims to study application of E-learning in jazan university showing its difficulties, advantages, staff views on outcomes and assessing overall situation of E-learning attempting suggestions and recommendations for an effctive role of web-based techniques.

To fulfill the requirements of the study, 3 related topics were introduced. These include:CCOVID 19, E-learnig (definition, types, advantages and difficulties) and history of E-learning in Jazan university.Thena questionnaire of three sections was designed (to show importance of E-learnig, staff qualifications and skills in using E-learning programams, and teaching environment i-e devices, internet, etc...). Questionaire items wre adjusted and edited according to the comments of 6 experts.Reliabity and validity of the items were tsted. The questionnaire was distributed to a small group, then after two months to the target group. Person's formula for correlation co-efficient was applied.The sample was 260 staff members. The questionnaire was administered to the target group through google forms.238 copies were collected. The study folloed the descriptive analytical method. Data was analyzed and discussed by tables and graphs. The study arrived at fruitful findings in favour of applying Elearning despite the current difficulties that can be removed. Based on the results, the study suggests procedures to improve E-learning efficiency and solve its problems.

The paper represents a key to wider discussion on E-learning. Future studies can deal with comlementry issues such as:students' attitudes, improving electronic assessment programs, future of E-learning.
\end{abstract}

Keywords- assessment. blackboard, COVID 19, E-learning, outcome.

\section{References:}

[1] 1.A.M.Jazeel:"Role of ICT in transforming Sri Lankan Higher Education"

[2] 2.Bates,A,W: "Effective teaching with technology in Higher Education" 
[3] Conceicao.S.C: "managing Online Instructor Workload strategies for Finding balance and Success"

[4] Mahalahshimi,h \&Radha,R: "Covid-19: A Massive Explosure to Web-based Learning"

[5] Mark ballen \&Diane.P:"Making the Transition to E-leaning Strategies and issues:

[6] V.Sath:"Global Impact of E-learning During covid-19"

[7] WHO reports.

[8] Jazan University Gate. 